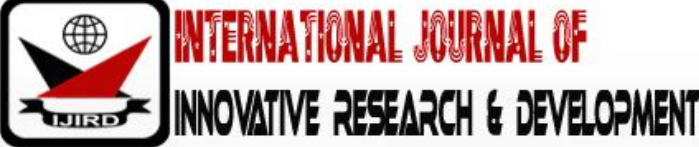

ISSN 2278 - 0211 (Online)

\section{Informal Motorcycle Business and Livelihoods in Urban Areas of Kenya: Evidence from Fldoret and Kakamega Towns}

\begin{tabular}{c}
\hline Kimeu Muindi \\
Lecturer, School Department of Entrepreneurship Studies Moi University, Kenya \\
Ojuki J. S. Nyabuta \\
Lecturer, Department of Entrepreneurship Studies, Moi University, Kenya
\end{tabular}

\begin{abstract}
:
In this study, we sought to expound the link between the revolution of the road transport sub-sector particularly motorcycle commonly known as boda boda and their potential to improve livelihoods and minimize the incidence of poverty. The empirical results from 57 motorcyclists operating in the two regions proved that there is a significant positive relationship with improved livelihoods. Our results illustrate the unique role played by boda business in alleviating poverty.
\end{abstract}

Keywords: Boda Boda, poverty, livelihoods, wealth creation, Kenya

\section{Introduction}

The existence and potential benefits of informal sector in Kenya's economy was given recognition and prominence following the publication in 1972 of the International Labour Organization's (ILO's) report on the unemployment situation in Kenya(ILO, 2014). Since then, the sector has continued to expand in scope, compexity and the type of small-scale businesses carried out, in addition to creating thousands of employment opportunities(Njenga, Kemtsop, Willilo, Opiyo, \& Hine, 2013). It has also gained much public and official policy support especially since the 1980's with many government policy documents tailored to it, to specifically nurture its growth through the provision of an enabling business and regulatory environment (Kenya, 1986; 1992; 1999; 2003).

One of the latest additions to the informal sector businesses with great potential to improve livelihoods and minimize the incidence of poverty, has occurred in the road transport sub-sector. In the last one decade or so, motorcycle - commonly known as boda boda, used for both commercial passenger and light freight transport, has revolutionized the road transport sub-sector in Kenya inrural and as well as urban areas (Njenga, et al., 2013). Motorcycle taxis have come with enormous advantages over other motorized modes of road transport that make them suitable for both rural and urban set-ups (Starkey, 2016). Many rural areas in sub-Saharan Africa, Kenya included, have poor road networks, hindering access to public transport(Yakubu, 2012).

People have to walk and goods moved over considerably long distances to get to the nearest road to access public transport(Yakubu, 2012). Lately, the emergence of informal commercial motorcycle taxis has tremendously reduced this burden. Traffic jams in major urban areas and poorly developed infrastructure in rural areas making motorcycles the preferred mode of transport over short distances for many Kenyans (The Standard, February 13, 2018). Moreover, motorcycles have become critical in delivery of supplies and parcels for both homes and businesses. Most companies with operations in Nairobi have invested in motorbikes (Ibid).

The impetus for the phenomenal emergence of commercial motorcycles in Kenya can be attributed to the socioeconomic and political changes that came in the aftermath of the 2002 general elections in which the coalition of opposition parties, National Rainbow Coalition (NARC) trounced, the then ruling party Kenya African National Union (KANU). KANU that has been in power since independence and had presided over much of the economic decline ${ }^{1}$ and deterioration of the human condition ${ }^{2}$ that took place in the 1980's and 1990's ${ }^{3}$ decades.

\footnotetext{
${ }^{1}$ Kenya's economic performance fell far below its potential. Growth of GDP in constant prices stood at 1.8per cent in 1998 and was expected to rise to 2.3per cent in 1999 (Kenya: Economic Survey, 1999, p. 2)

${ }^{2}$ Number of people openly unemployed stood at 2million 2003or 14.6per cent of the labour force, with the youth accounting for 45per cent of the total. Number of people living in poverty rose 11million or 48per cent of the population in 1990 to 17 million or 56per cent in 2001(Kenya, 2003, Executive
} 
Thus KANU's inability to reverse the trend was no longer in doubtin the minds of the citizenry that overwhelmingly voted in an alternative regime. On taking over power in 2002, NARC embarked on a path of revival of the economy and openning up the democratic space. The Ministry of Planning and National Development published a blue print that was to guide the country on its path to recovery, Economic Recovery Strategy for Wealth and Employment Creation, 2003 -2007.The blue print identified the root causes of the economic decline as mismanagement, corruption, unmanageable borrowing in the domestic market, poorly conceived public investments, wastefulness, general bad governance in the government and public sector, political oppression and weak implementation of otherwise good policies (Government of Kenya, 2003; Omolo, 2012). As a result, the blue print notes, "poverty has increased, unemployment has become rampant, insecurity has visited almost every homestead, hunger is rampant among the poor..."(Ibid).Thus, at the very outset, the NARC administration was quite clear what it wanted to do to get Kenya back on track to economic recovery and human dignity and states in the blue print:

This Economic Recovery Strategy for Wealth and Employment Creation aims at giving Kenyans a better deal in our lives and in our struggle to build a modern and prosperous nation. It aims to empower Kenyans and to provide them with a democratic political atmosphere under which all citizens can be free to work hard and engage in the productive activities to improve their standards of living(Ibid, p. V)

It is against this backdrop of a changed political and changing policy environment that the phenomenal emergence in Kenya of the informal commercial motorcycle operations needs to be assessed. The macro-economic framework espoused in the recovery program informed the lowering of import taxes on motorcycles. The aim was to make motorcycles affordable to low income families who could put them into commercial use thus improving their income sources. Since 2008, this policy has been pursued consistently, with the result that imports of motorcycles has increased tremendously as reflected in the trend of registration in the table below:

\begin{tabular}{|c|c|c|c|c|c|}
\hline $\mathbf{2 0 0 9}$ & $\mathbf{2 0 1 0}$ & $\mathbf{2 0 1 1}$ & $\mathbf{2 0 1 2}$ & $\mathbf{2 0 1 3}$ & Total \\
\hline 91,151 & 117,266 & 140,215 & 93,970 & 125,058 & 441,466 \\
\hline
\end{tabular}

Table 1: New Motor and Auto Cycles Registered in Kenya, 2009 - 2013

Source: Economic Survey, 2014

The overall benefit ofthis has been to make the motorcycles affordable to many poor households. Available industry data indicate that in 2015 and 2016, about 182,000 and 146,000 motorcycles, respectively worth Sh 10.7 billion and Sh 8.2 billion were brought into the country.

It is imperative that the informal commercial motorcycle mode of transport is a major player in employemt creation and income generation in Kenya. Citing industry figures, popular print media put the number of commercial motocycles on Kenyan roads at 600,000, with each estimated to be making, on average, Sh 1,000 a day. This translates to Sh. 600 million a day or Sh. 219 billion annually (The Standard, February 13, 2018). Further industry estimates indicate that about eight people depend on each motorcycle in operation for their daily livelihood. This translates to about 4.8 million people who depend on motorcycles (Ibid)

Despite the potential as a huge source of livelihood (providing employment opportunities and incomes), eradicating poverty and stimulating economic development, not much valuable and insightful research has been done on the operations of commercial motorcycle businesses in Kenya to ascertain precise levels of such benefits. Even official government sources such as Economic Surveys and Statistical Abstracts, still lump information on motorcycles together with the rest of informal sector businesses. There is for example no disaggregation of data to show earnings, jobs, ownersip structure, gender relations and sources of funding associated with boda bodaoperations.

The evidence that exists comes from scanty literature, mainly student dissertations. What is more such available literature relate to rural rather than urban areas and concentrate on issues of regulation, safety, accidents and transport services (eg. (Njenga et al., 2013; Singoro, Wakhungu, Obiri, \& Were, 2016). Although Starkey (2016) discusses funding sources and prices charged, the study is wide, covering many countries of Africa and is thus not specific to the Kenyan situation.

This study therefore sought to explore the potential of commercial motorcycle operations in improving livelihoods, alleviating poverty and contributing to the general development of the economy. In particular, it focused on the earnings of the operators, improvement of household incomes, sources of funds, benefits to the communiy, utilization of funds accruing and spill-over effects (i.e projects initiated as a result of boda boda businesses). The overall aim is to stimulate policy debate around how best to streamline the boda boda business for purposes of tapping on its potential to improve living standards of the poor unemployed youths who dominate it in the context of general economic empowerment.

\section{Summary viii)}

3The 1980's decade was a lost decade' for most of sub-Saharan African countries. The trend of decline continued in the 1990's and the economies grew by on 3per cent, 2.3per cent, and 1.5per cent in 1990, 1991 and 1992 respectively (Rasheed, S. 1993. The Challenge of Sustainable Development in Africa in the 1990's and Beyond",EASSRR, Vol. IX, No. 2, p. 2)These figures compare with the figures Kenya's own economy registered 
The rest of this article is structured as follows: in section 2 we provide a brief literature survey; in section 3 we present the methodology of the study. Section 4 contains the results while in section 5 we present discussion of the results. In the final sectionwe prest conclusion and recommendations for further research.

\section{Literature Review}

Literature on boda boda operations in urban Kenya are still few and far between despite the widespread phenomenon of this business in nearly all urban centres of Kenya. However quite insightful findings have been obtained from rural (in some instances urban) settings both in Kenya and in other African countries.

Karema (2015)studied the role of motorcycle in promoting agriculture in the rural economy of Kenya using a case study approach and found out that the commercial motorcycles contribute to poverty alleviation amongst rural dwellers. This is mainly because motorcycle businesses trigger multiplier effects through production and consumption. A number of economic activities emerge as a result of commercial motorcycle ridership. These include roadside small shops (kiosks), sale of motorcycle spare parts, repair of motorcycles, intensive cattle raising and poultry keeping. All these economic activities generate gainful employment and have potential to reduce poverty by upto 10per cent.

In rural Tanzania, Willilo and Starkey (2012) and Kemtsop and Starckey (2013) found out that motorcycle taxis are far too important as the only motorized means of transport available in rural roads. Movement of people as well as of small amounts of freight depend nearly entirely on motorcycles. The benefits of motorcycles here to the sick, pregnant women and the elderly who need medical attention, and hence quick transport services, are spectacular, as motorcycles are the ambulance. These categories of users as well as the small-scale traders rate motorcycles very highy for their transport services. Hower \& Davis (1999) report similar findings in rural Uganda where boda bodabusiness comprises both bicycles and motorcycles.

Arosanyin, et al. (2011) used a case study to examine the employment generation and determinants of earnings from the informal commercial motorcycle transport in Nigeria. The findings reveal that the sector generates employment to 21.7per cent of jobless people and 72.3per cent of those who switched jobs from one informal activity to the transport sector. Job switching within informal sector signifies the perception that one informal sector job could be as good as any other. This is confirmed by the finding in this study that the probability that a motorcyclist would earn at least the informal sector average in the Okada (boda boda) business when the operator is has a driver's license, owns the motorcycle, works on full time basis and also a member of okada union is 0.8018 , compared to 0.2849 for operators with reverse attributes. The study further found that household size, experience and operating hours were the key determinants of eranings in motorcycle transport sector.

These findings on determinants of earnings are confirmed in Yakubu (2012) from another Nigerian setting, Kwara State. In particular, licensing seems to be not only a key determinant of earnings (licensed operators earn N 512.37 higher than non-licensed operators daily). It is also a critical factor in regulation. As Arosanyin, et al. (2011) suggest, employment and earnings in the sector can be improved if the government regulates the operations and segregate traffic. Licensing would be one avenue to achieving effective regulation. Further improvements in earnings and employment according to Arosanyin (2010) can be achieved by addressing the critical constraints which are identified as: bad roads, police extortion, high running costs and harassment from other motorized traffic.

A running theme in most researches on commercial motorcycle transport sub-sector in Africa is regulation as it relates to safety of passengers and riders alike (Singoro, et al., 2016; Starkey, 2016; Raynor, 2014; Arosanyin, 2010). These studies agree that compliance with with fiscal and safety regulations is wanting. In particular, Starkey (2016) points out that many motorcycle drivers do not have a driver's license and very few have had any training relating to safe driving, traffic regulations or road safety. As a result many fatal traffic accidents and injuries occur. It is for this reason that Singoro, et al., (2016) propose such measures as training of motorcycle drivers, observing speed limits, improved roads, not driving while under the influence of alcohol/ drugs, no over loading, lawful enforcement by police, maintenanceamong others.

\section{Methodology}

\subsection{Study Area}

This study was carried out in Eldoret and Kakamega towns. Eldoret is a cosmopolitan town located some $310 \mathrm{~km}$ west of Nairobi. It is the fifth largest town in Kenya. It is growing rapidly and offers an assortment of leisure and business facilities as the hub of the North Rift and administrative centre of Uasin Gishu County. This Town has several collections of boda boda cyclists dotted in various designated points as part of the town's authorities' regulation mechanism. The same applies to Kakamega town that lies some 270 kilometres from Eldoret town. Kakamega is the Headquarters of Kakamega County.

\subsection{Data Type and Collection Method}

This study used cross-sectional data, collected in 2017 through a survey using questionnaires. Some 102 questionnaires were distributed to boda boda operators as well as residents in the study area. Of the 102 questionnaires distributed, 57 were successfully filled and collected back for analysis. 


\section{Results and Interpretation}

\subsection{Demographic Characteristics of the Respondents}

Figure 1 below shows the ages of the boda boda operators whereby 68.4per cent (39) were below 40 years and 31.6 per cent (18) were above 40 years of age.This means that in essence more young people are engaged in the boda boda business as opposed to more elderly ones which can be attributed to the health risks associated with the business and its low income yields as compared to other enterprises.

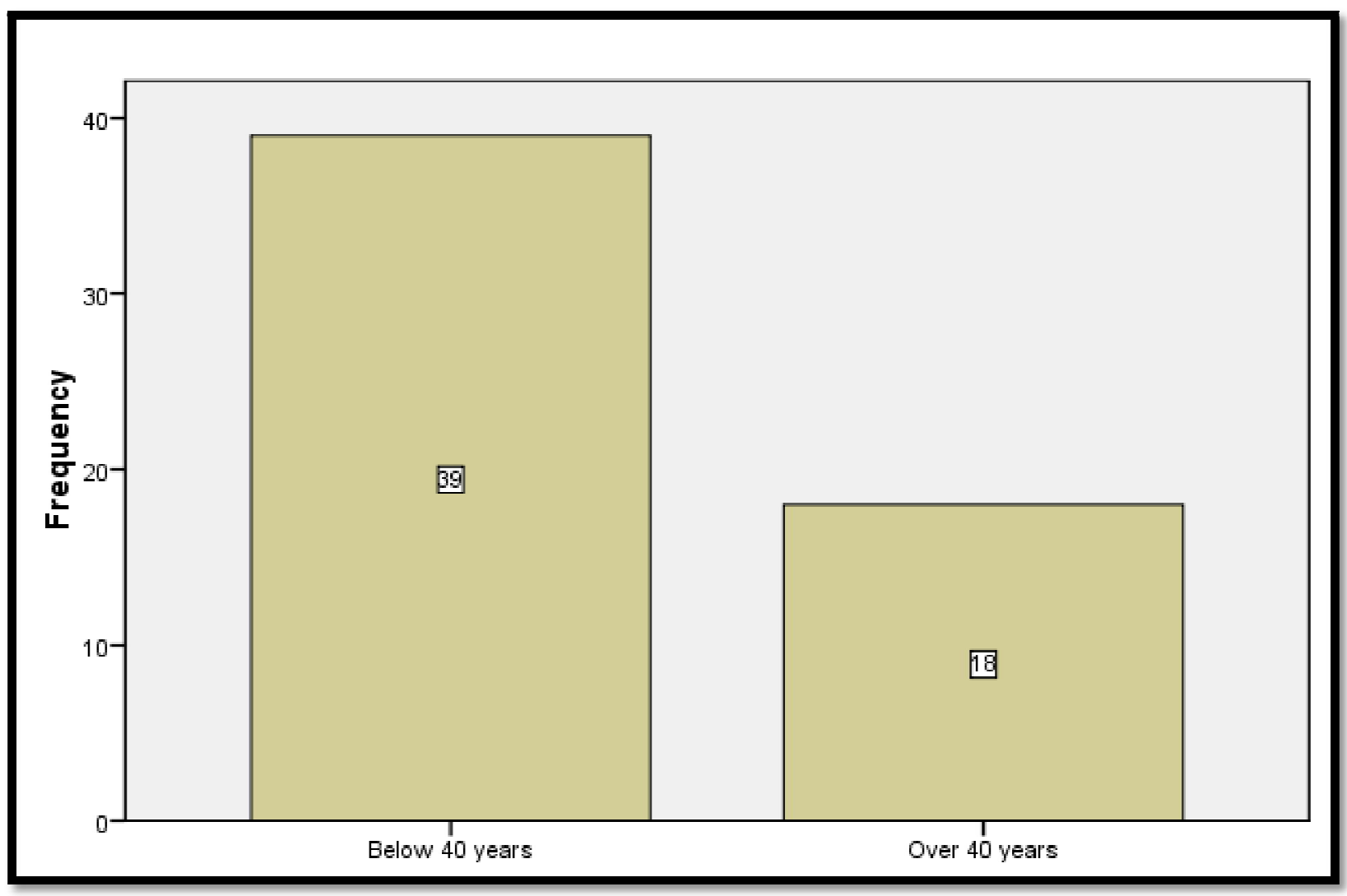

Figure1: Age Distribution

\subsection{Results}

The main aim of this study was to examine the potential of commercial motorcycle operations in improving livelihoods, alleviating poverty and contributing to the general economic empowerment of the several unemployed youths engaged in the business. In particular, it focused on the earnings of the operators, improvement of household incomes, sources of funds, benefits to the communiy, utilization of funds accruing and spill-over effects (i.e projects initiated as a result of boda boda businesses). To achieve these objectives, the study posed 15 questions to the respondents to get their opinions

\subsubsection{The Main Transport Problems in Eldoret and Kakamega Towns}

Out of the 57 respondents, 29.8per cent (17)believed that the main transport problem in their area was due to poor roads, 14per cent (8) believed it was high bus fares which were out of reach for the common citizens, 5.3per cent (3) believed it was scarcity of public buses and matatus, a staggering 38.6per cent (22) believed it was high boda boda fares, while 12.3per cent (7) believed there was no transportation problem see 4.22. This in essence means that the biggest single challenge in terms of transportation facing people in Eldoret and Kakamega towns is high boda boda fares which can be attributed to the existence of poor roads and hence the need to charge a price sufficient for maintenance purposes. 


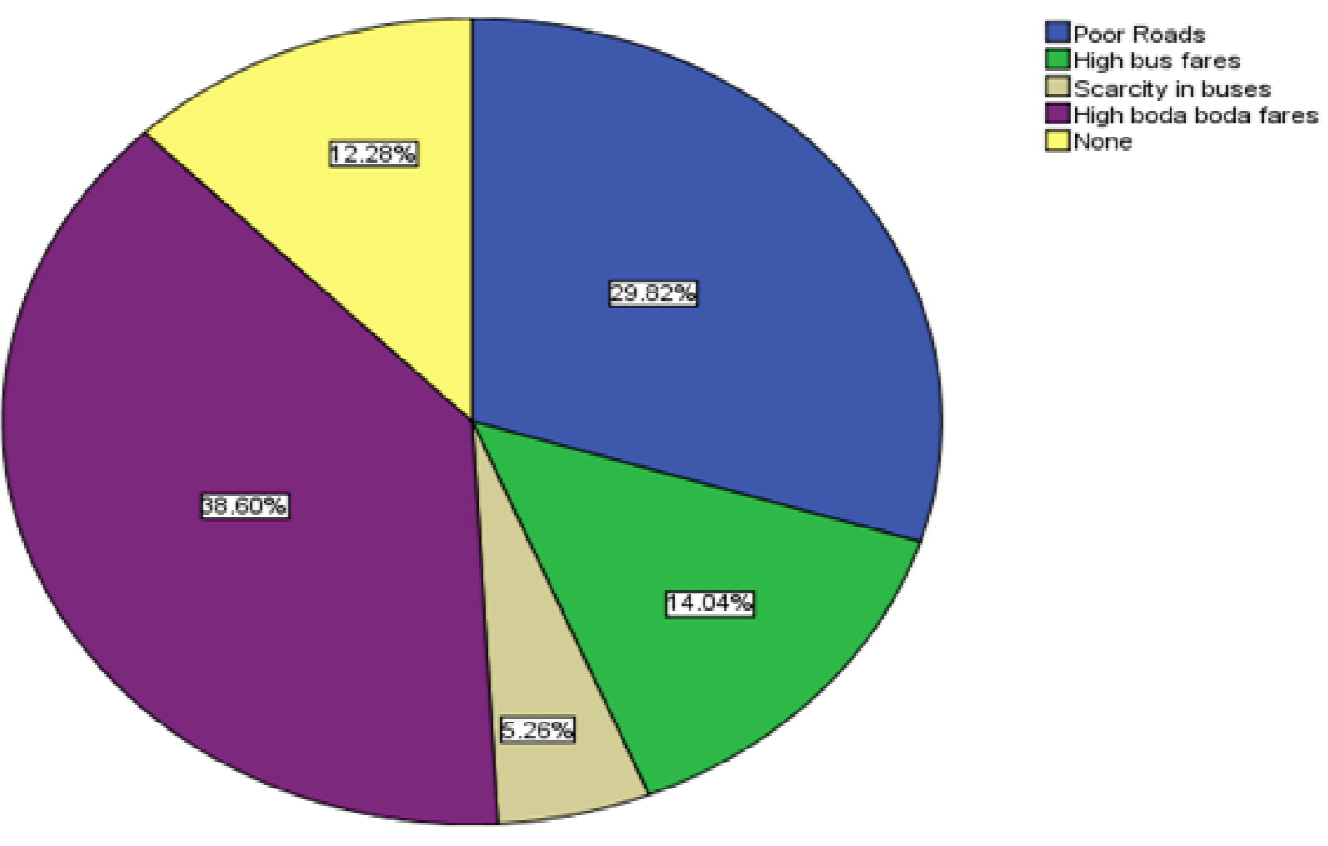

Figure 2: Main Transport Problems Facing People in Eldoret and Kakamega Towns

\subsubsection{Boda Boda Business's Contribution to the Kenyan Economy}

52.6per cent (30) of the respondents believe that the boda boda business has contributed hugely to the enhancement of the Kenyan economy at 29.8per cent (17) of the respondents believed that the boda boda business has contributed to the Kenyan economy although not very much, while 14per cent (8) of the respondents were of the respondents were of the opinion that the boda boda business has not contributed anything to the development of the Kenyan economy as shown in figure 3 below. This means that the boda boda business has contributed to the development of the Kenyan economy hugely mainly due to provision of income, job opportunities to otherwise jobless Kenyans as well as easing the transportation of both humans and produce to the markets in good time.

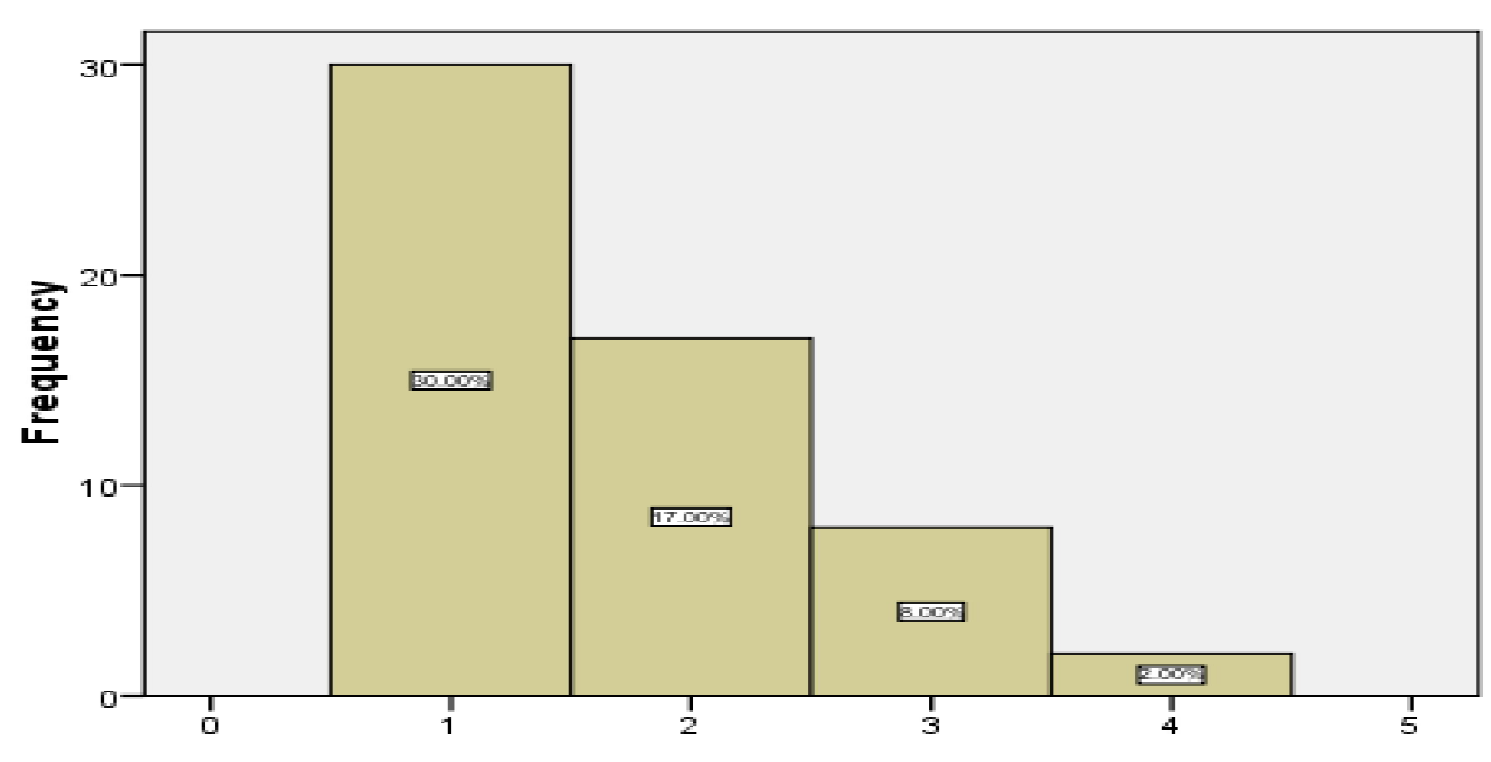

Mean $=1.6 \mathrm{~B}$ 


\subsubsection{Effects of Boda Boda Business in Alleviating Poverty among Households}

The respondents were asked if they felt that the boda boda business had made impact in alleviating poverty in their households. 56.1per cent (32) of the respondents believed that the business had helped them a lot in alleviating poverty, 33.3per cent (19) of the respondents believed it had helped them but just a little, 3.5per cent (2) of the respondents believed that the business was not successful in alleviating poverty in their households, while 7per cent (4) of the respondents were not sure if the business had helped them in alleviating poverty in their households or not as shown in figure 4 below. This can be interpreted to mean that the boda boda business has been successful in alleviating poverty from most households in the region largely due to increased employment options and increased incomes.

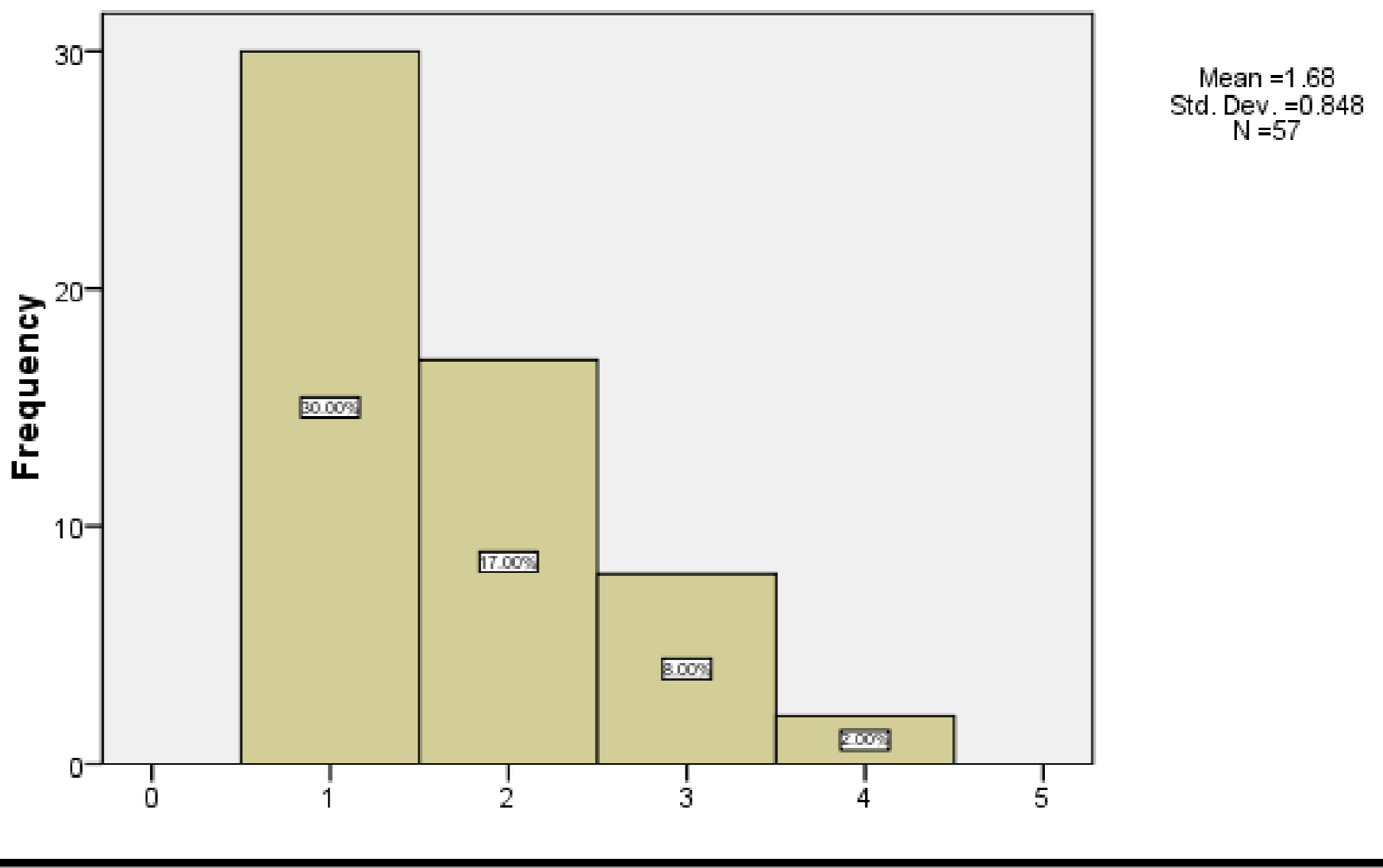

Figure 4: Effects of Boda Boda Business in Alleviating Poverty in Households

\subsubsection{Areas of Improvement in the Households' Incomes}

The respondents were asked to state what things had improved in their households and a staggering 70.2per cent (40) of the respondents mentioned education as the area most improved, 3.5per cent (2) of the respondents stated capital investments as the area largely improved in their households, 8.8per cent (5) of the respondents stated that housing had improved massively, while 17.5per cent (10) of the respondents believed that the general living standards had improved in their households. Figure 5 below is a graphical representation of the results. This means that education has been the largest beneficiary of improved incomes from boda boda business as parents seek to educate their children for a better and secure future. 


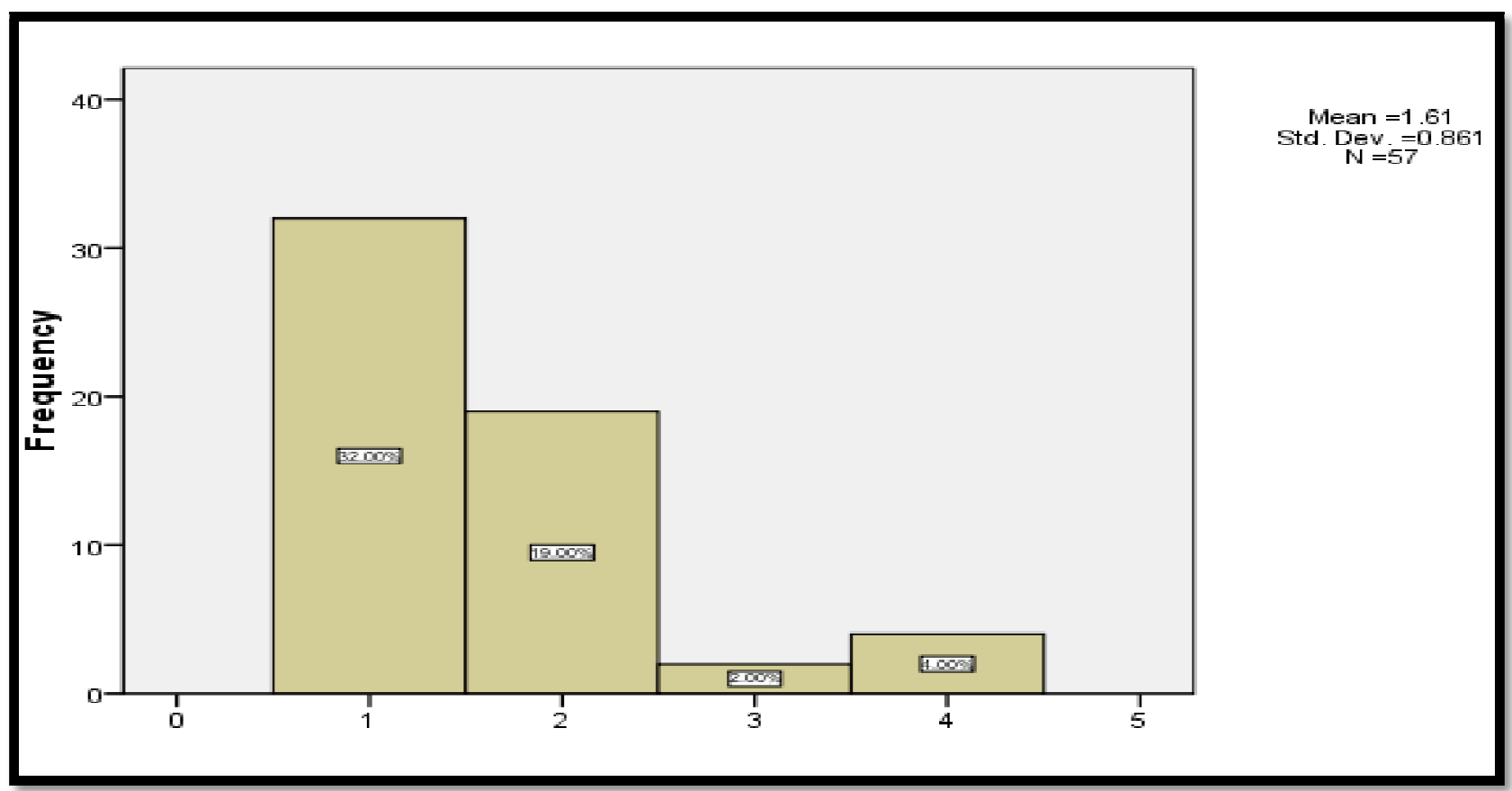

Figure 1: Areas of Improvement in the households

\subsubsection{Knowledge of the Various Traffic Rules}

This question sought to test the knowledge of the respondents on the various rules governing the management and running of the boda boda business as set out in various Acts. 12.3per cent (7) of the respondents said that they were aware of the rules, 35.1per cent (20) of the respondents said they were not aware of the existing rules and Acts governing their operations and business, 47.4per cent (27) of the respondents were somehow aware of the rules, while 5.3per cent (3) of the respondents had no opinion concerning the same as shown in figure 6 below. This in a nutshell means that there exists ignorance on the rules and acts governing the management and operation of boda boda business in Kenya mainly due to poor civic education by the government and civil society to educate and sensitize boda boda operators and users on the existing laws.

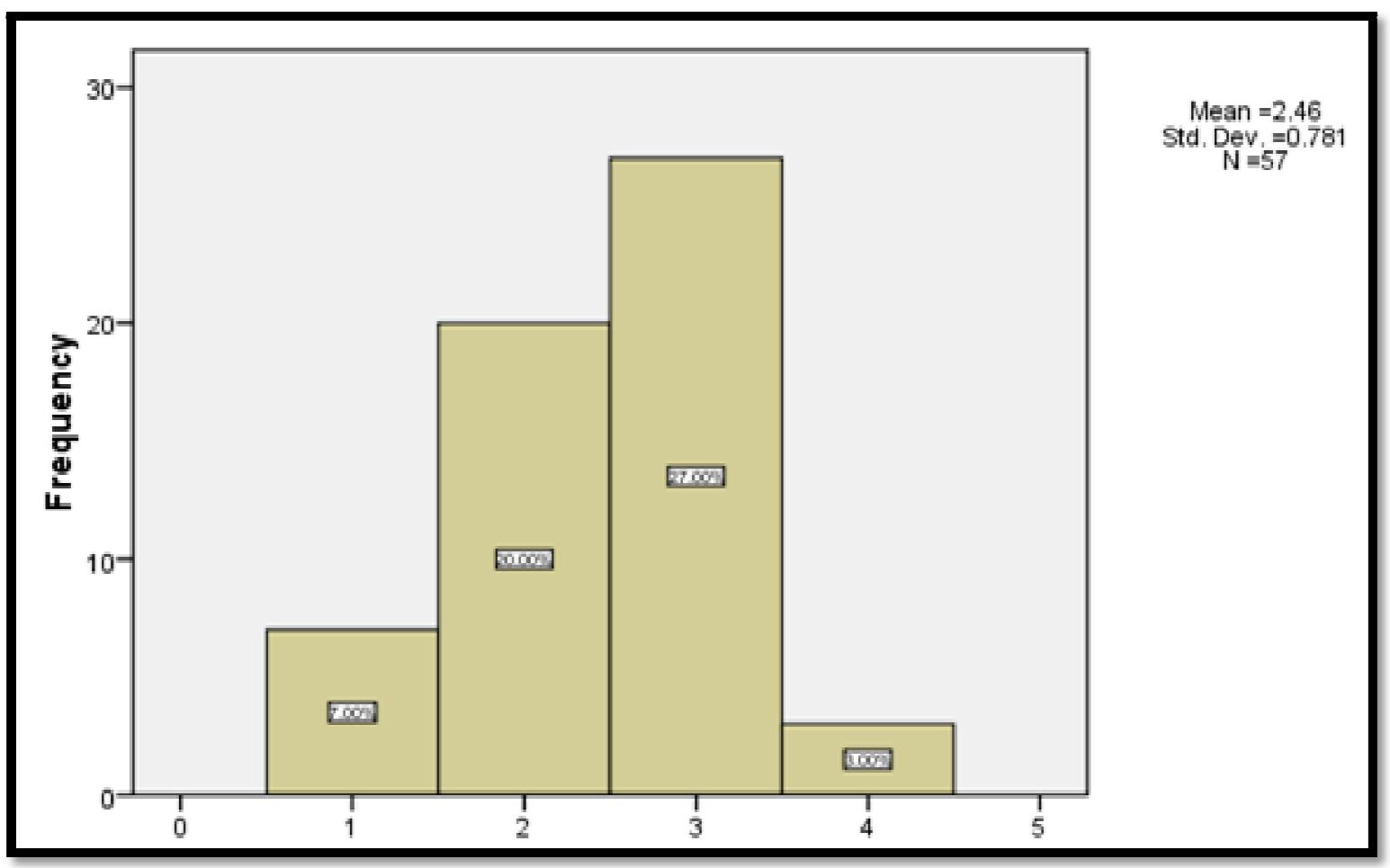

Figure 6: Knowledge of the Various Rules Governing the Management and Running of the Boda Boda Business as Set out in Various Acts 


\subsubsection{Benefits to the Community from the Boda Boda Business}

The respondents were asked if they believed that the local community had benefited from the boda boda business and a staggering 78.9per cent (45) of the respondents agreed, 15.8per cent (9) of the respondents disagreed with the statement, while 5.3per cent (3) of the respondents reserved their opinion as shown in the figure 7 below. This means that majority of the boda boda operators and users believe that the local community has benefited immensely from the boda boda business.

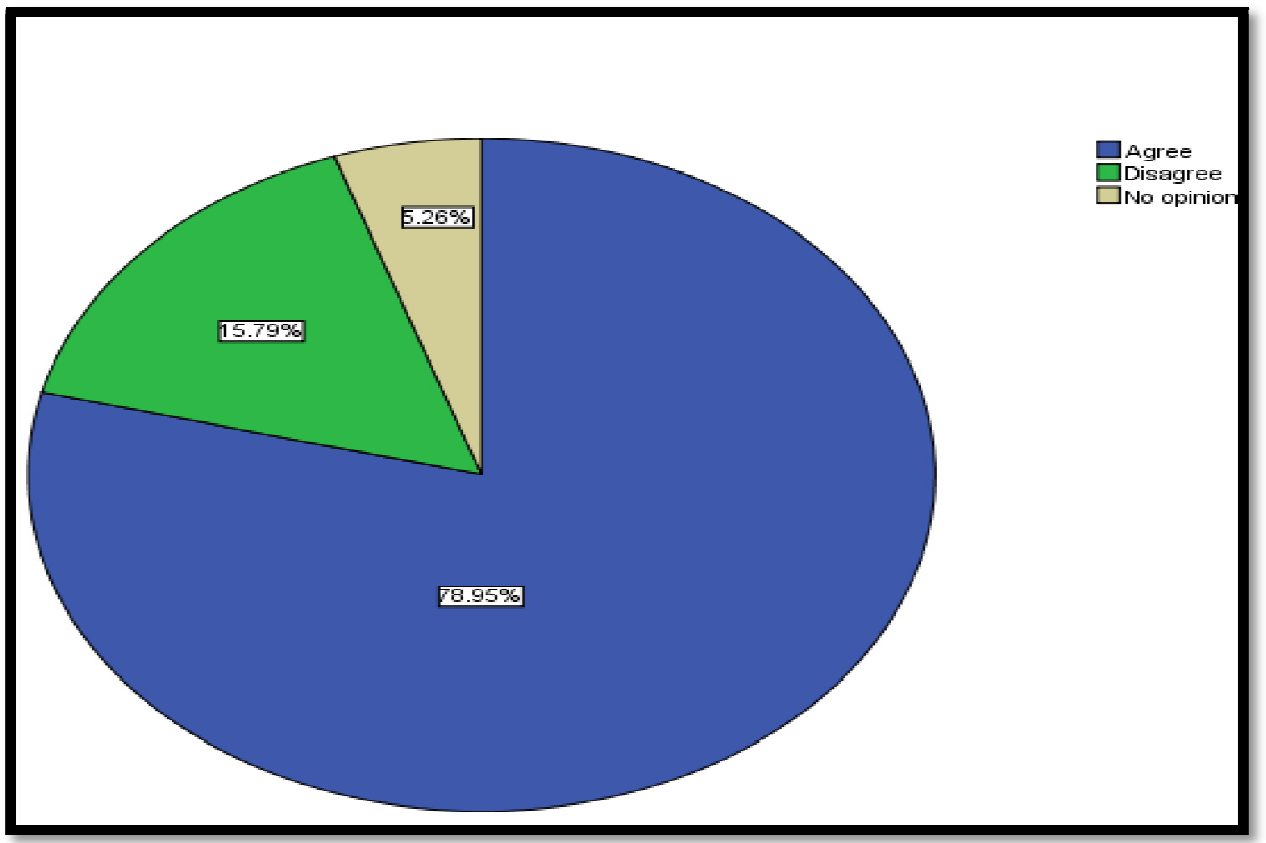

Figure7: Benefits to the Community from the Boda Boda Business

\subsubsection{Optimum Method of Appointing Boda Boda Association Officials}

The respondents were asked if they believed that the method of appointing boda boda association officials was optimum and only 17.5per cent (10) of the respondents agreed with the question, a staggering 78.9per cent (45) of the respondents disagreed with the questions, while 3.5per cent (2) of the respondents had no opinion. This is shown in figure 8 below. This can be interpreted to mean that majority of the boda boda operators believe that the process of choosing or electing officials to the boda boda association is skewed mainly due to corruption and intimidation claims.

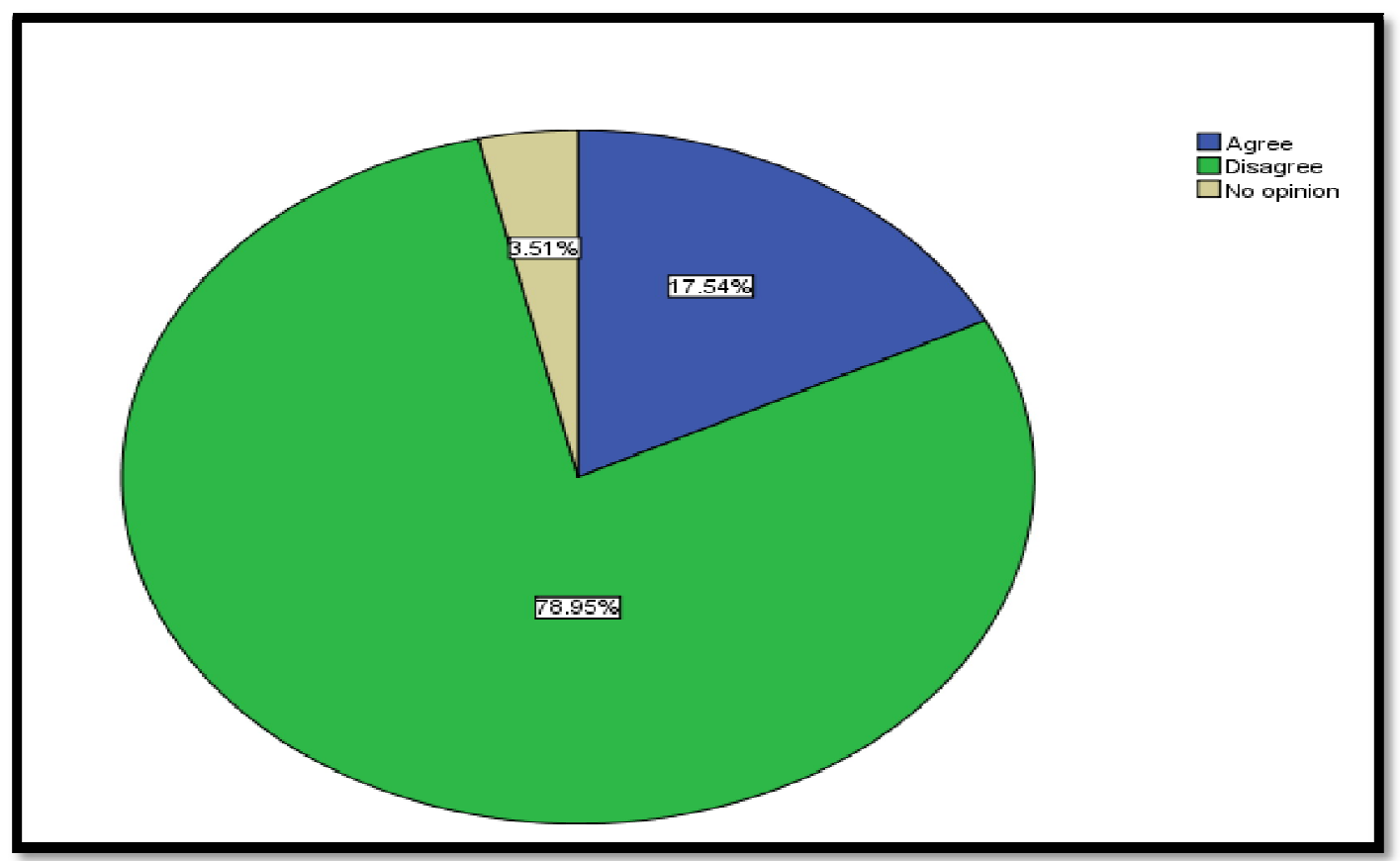

Figure 8: Optimum Method of Appointing Boda Boda Association Officials 


\subsubsection{Marked Improvements in Earnings as Compared to Previous Engagements}

The respondents were asked if there was marked improvements in earnings as compared to their previous engagements and a massive 66.7per cent (38) of the respondents agreed with the question, 17.5per cent (10) of the respondents disagreed with the statement, while 15.8per cent (9) of the respondents had no opinion concerning the same as shown in figure 9 below. This means that there has been marked improvement in earnings as compared to the previous engagements by the boda boda operators mainly due to the fact majority were casual labourers, unemployed or peasant farmers.

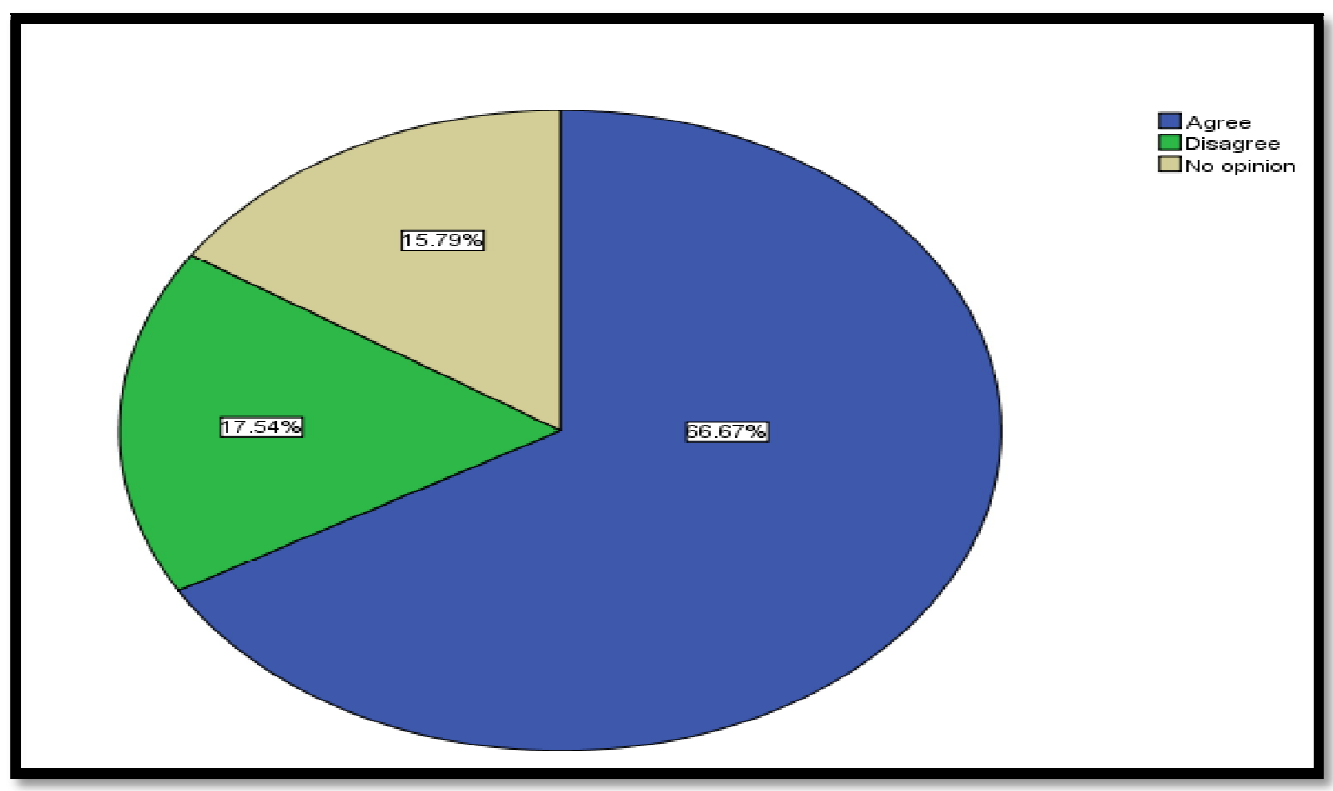

Figure2: Marked Improvements in Earnings as Compared to Previous Engagements

\subsubsection{Room for Growth and Advancement of Oneself in the Boda Boda Business}

The study asked the respondents if they believed that there was a room for growth and advancement of oneself in the boda boda business and a whopping 91.2per cent (52) of the respondents agreed with the question, 3.5per cent (2) of the respondents disagreed with the question, while 5.3per cent (3) of the respondents had no opinion as shown in the figure 10 below. This means that almost all the boda boda operators and owners hold a strong believe that they can better their lives through their boda boda business.

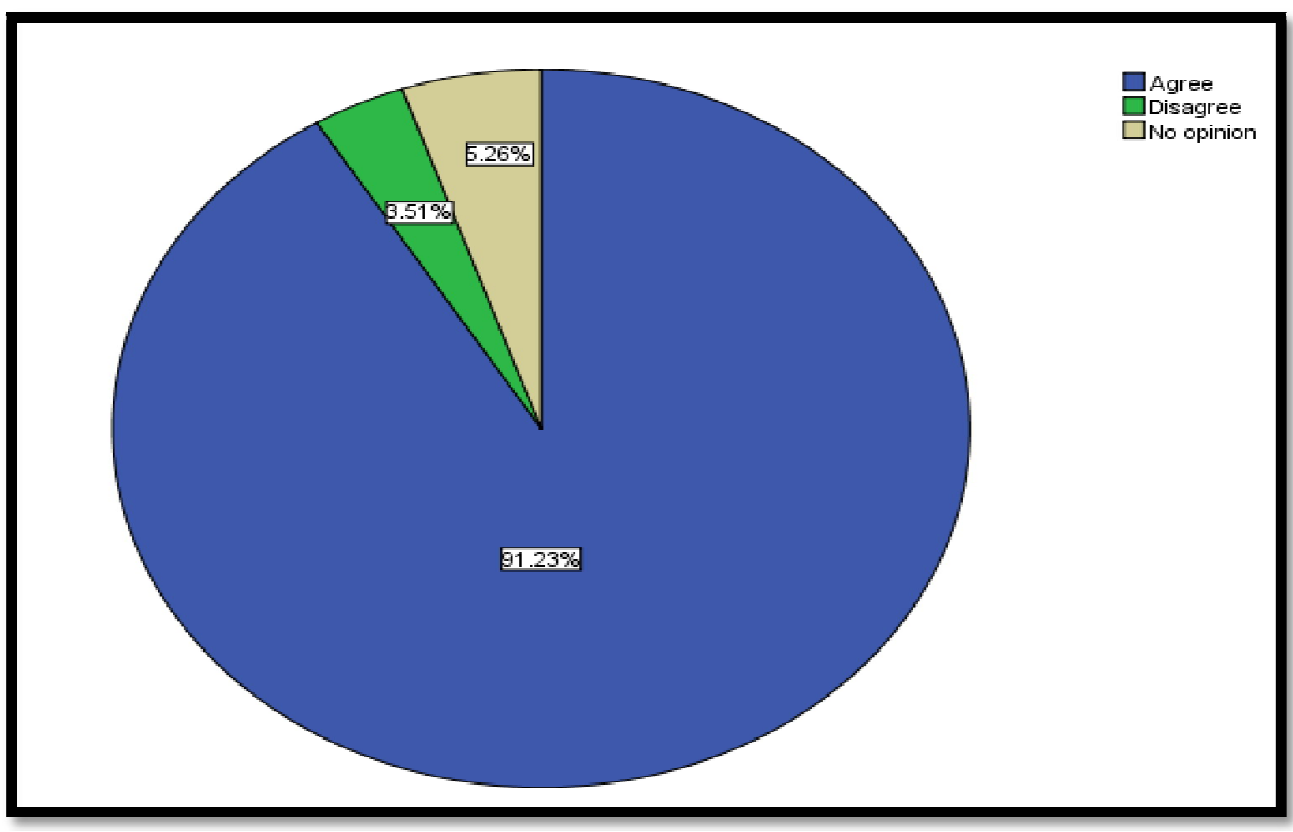

Figure 3: Room for Growth and Advancement of Oneself in the Boda Boda Business 


\subsubsection{Utilization Ofincomefrom Boda Boda Business by Peers and Associations}

Respondents were asked if they felt that the income from boda boda business had been fairly utilized by their peers and association and 29.8per cent (17) of the respondents said that the income utilization was very well coordinated, 35.1per cent (20) of the respondents felt the income utilization was fairly well coordinated, 28.1per cent (16) of the respondents believed the income utilization was not well coordinated, while 7.0per cent (4) of the respondents did not know how the income was been utilized as shown in figure 11 below. This means that the income from boda boda business has been fairly well utilized by the operators although a good number of the operators misuse their income.

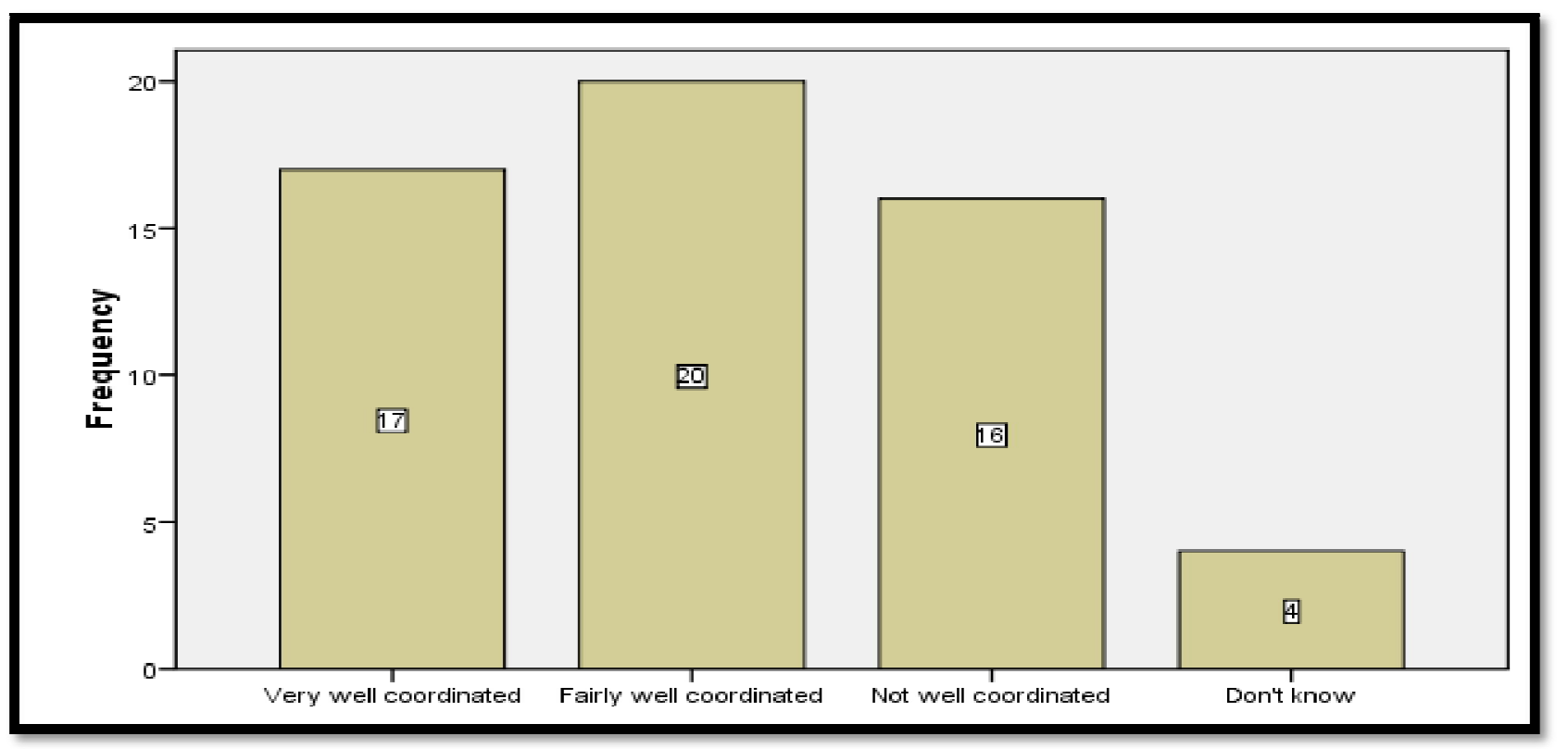

Figure4: Boda Boda Business Income Utilization by Peers and Association

\subsubsection{Rojects Funded by the Boda Boda Business in the Area}

The study asked the respondents if they knew any project or anything else that had been funded out of the boda boda business in their area and 42.1per cent (24) of the respondents said yes, 28.1per cent (16) of the respondents said no, 26.3per cent (15) of the respondents said they knew some projects but were not sure where the money came from, while 3.5per cent (2) of the respondents said they do not know of any project as shown in figure 12 below. This means that there have been substantive projects in the region funded by money from the boda boda business.

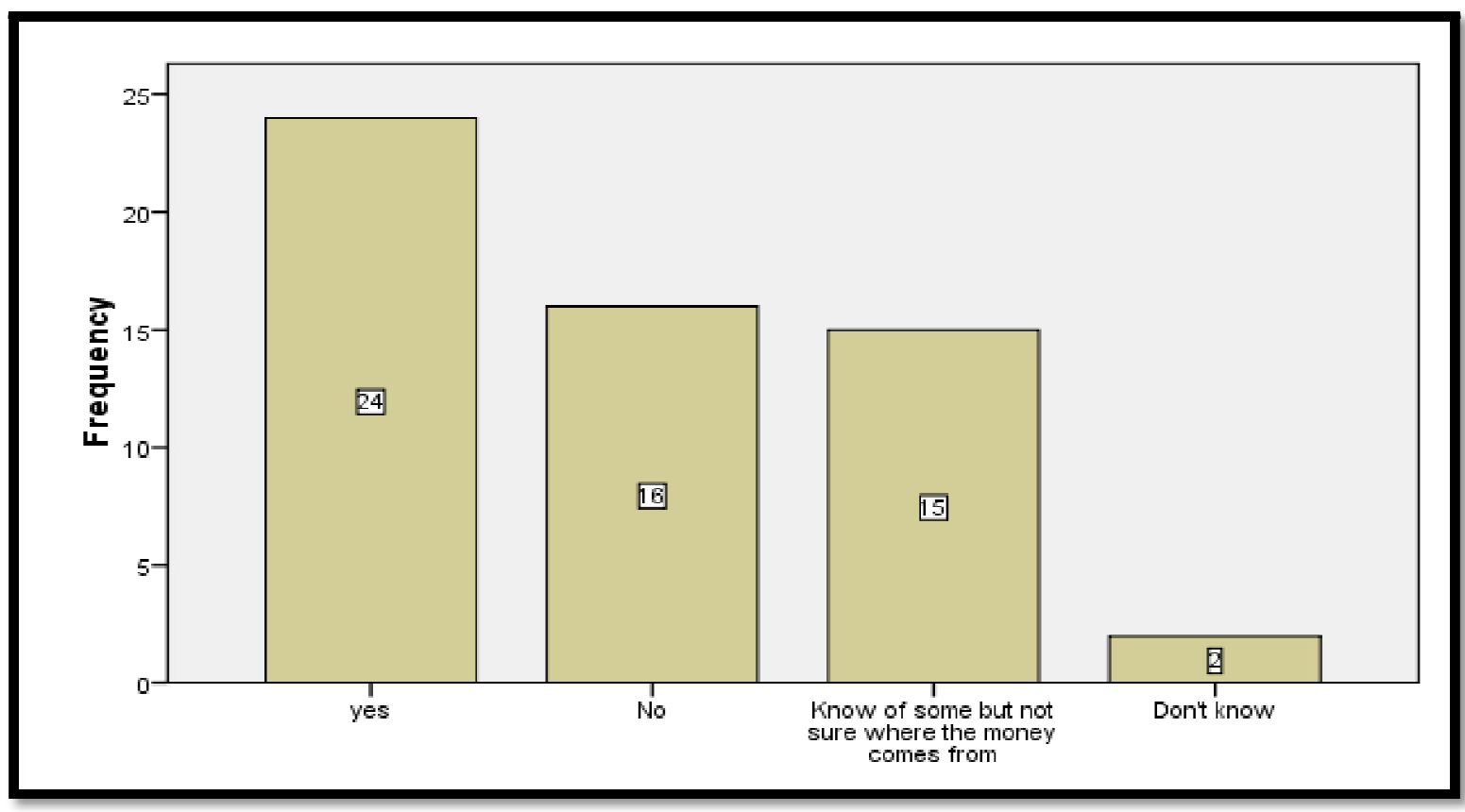

Figure5: Projects Funded by the Boda Boda Business in the Area 


\subsubsection{Boda Boda Business's Contributions to Overall Livelihood Improvements among Households}

The respondents were asked how much, if at all, they felt that the boda boda business had contributed to the improvements in livelihoods in the households as whole and 54.4per cent (31) of the respondents said a lot, 33.3per cent (19) of the respondents said a little, 8.8per cent (5) of the respondents said not at all, while 3.5per cent (2) of the respondents were not sure as shown in figure 13 below. This means that the boda boda operators feel that the business has led to great improvements in their livelihoods.

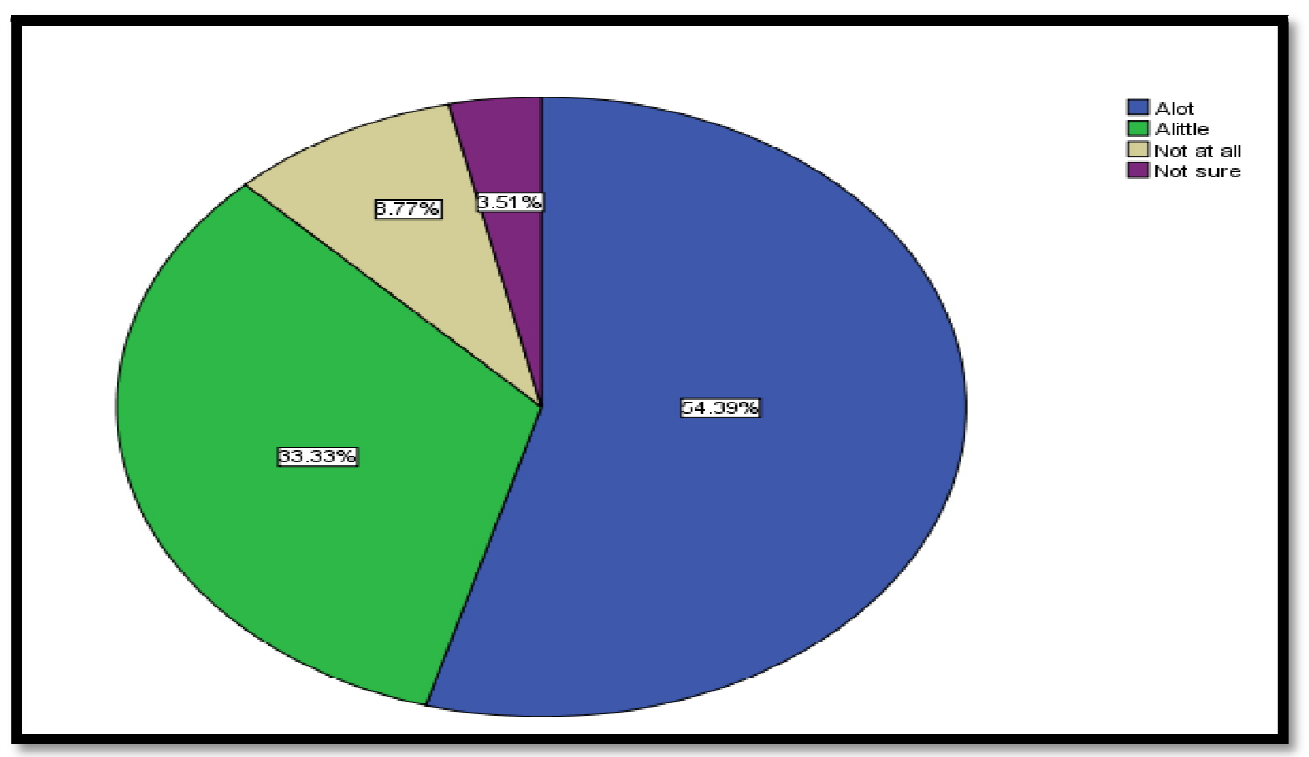

Figure6: Boda Boda Business Contributions to Overall Livelihood Improvements in Households

\subsubsection{Projects Undertaken as a Result of Boda Boda Business}

Respondents were asked to state what projects they had undertaken as a result of the boda boda business and the results were as follows; 3.5per cent (2) of the respondents said they had invested in matatus, 47.4per cent (27) of the respondents indicated they had invested in small kiosks, 1.8per cent (1) of the respondents indicated they had invested in a large retail shop, 17.5per cent (10) of the respondents said they had invested in small scale farming, while 29.8per cent (17) of the respondents said they had reinvested in the boda boda business as shown in the figure 14 below. This means that majority of the boda boda business operators have invested in other small projects owing to the nature and amount of income they get from their businesses. 


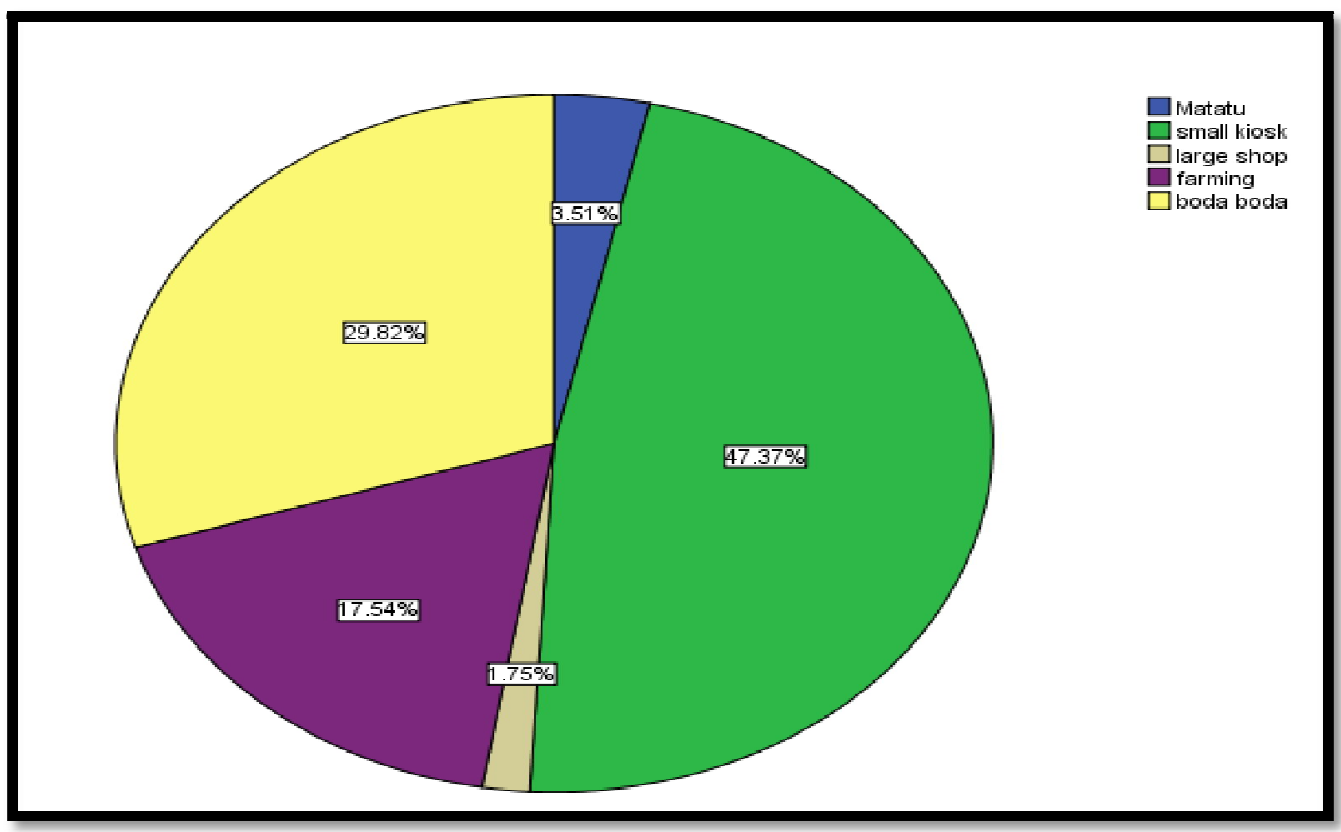

Figure 7: Projects Undertaken as a Result of Boda Boda Business

\subsubsection{Sources of the Project Funds}

The respondents were asked if these projects had been funded fully by the boda boda business or they had outsourced funds. 36.8per cent (21) of the respondents said that their projects had been fully funded by the boda boda business while 63.2per cent (36) of the respondents said that they had outsourced funds from other sources in addition to the funds from the boda boda business as shown in figure 15. This in essence means that most projects started by the boda boda operators are financed partly by their income and partly by other sources especially bank loans and family grants owing to the small income nature of the boda boda business.

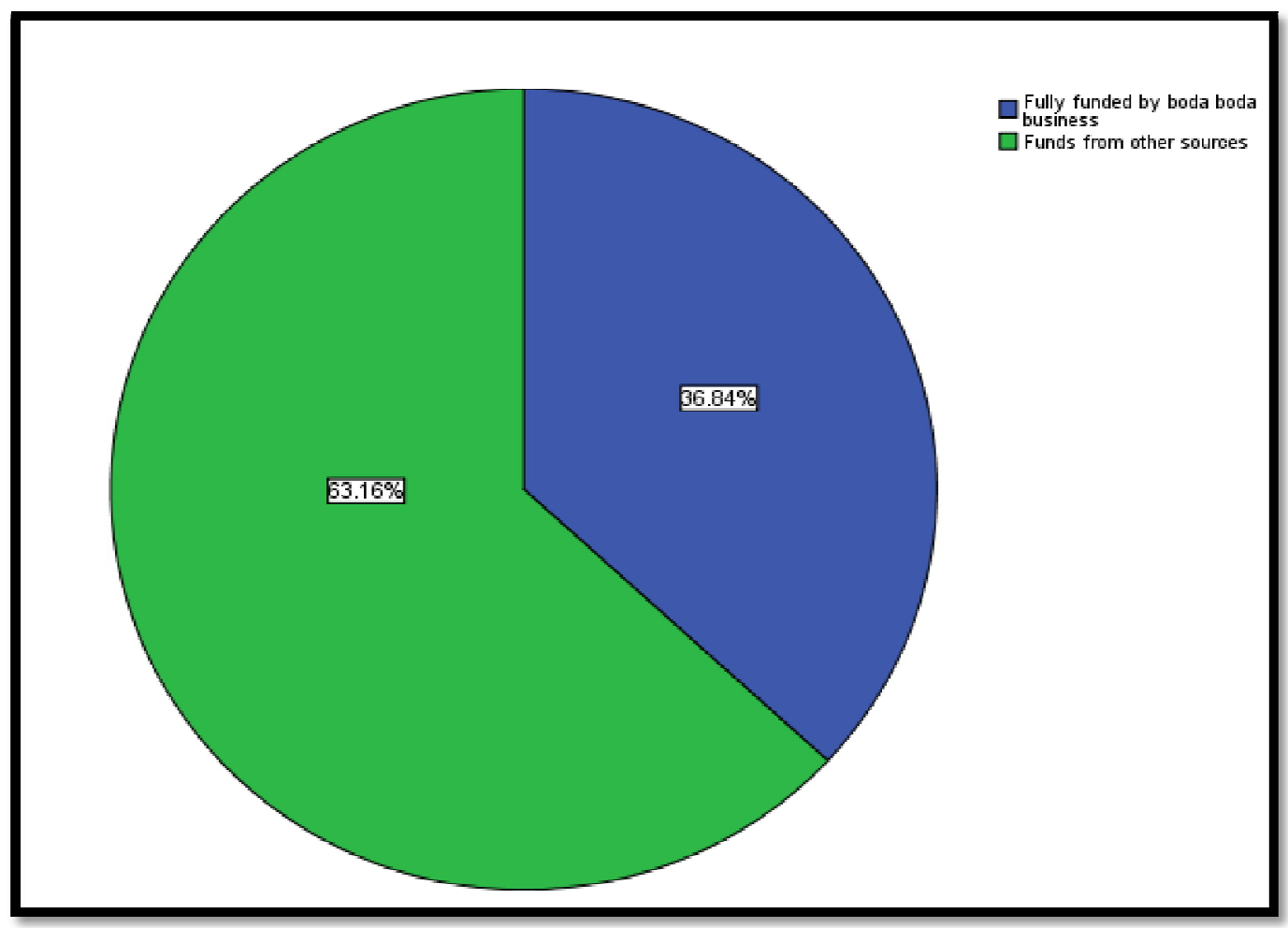

Figure8: Sources of the Project Funds 


\section{Discussion}

The government waived import duties on motor bikes in 2008 aimed at making them affordable to a majority of rural and urban population who rely largely on non-motorized means of transport. This led to explosion of motorized transportation in rural and urban areas with the effect of transforming rural economies. This research project sought to explore this phenomenon and expound on its relationship with alleviation of poverty among low-income earners in Kenya with specific focus on Eldoret and Kakamega towns.

\subsection{Boda Bodabusiness and Incomes Growth}

This study posed three questions to the respondents on the viability of the boda boda business as an option for transport services provision focusing on incomes; what the main transport problems faced by people are, in Eldoret and Kakamega towns; how the boda boda business had contributed to the development of the Kenyan economy as a whole; and if they believed that the local community had benefited from theboda boda business. 38.6per cent (22) of the respondents felt that the main transport challenge facing them was high boda boda fares caused by poor interconnecting roads and scarcity of efficient public service buses. 52.6per cent (30) of the respondents believed that the boda boda business had great role to play in the Kenyan economy as a whole while 29.8per cent (17) of the respondents believed that the boda boda business has contributed to the Kenyan economy although not very much. A staggering 78.9per cent (45) of the respondents believed that the local community had benefited from the boda boda business.

\subsection{Ownership of The boda Boda Business}

To achieve this specific objective, the respondents were asked 4 questions including; the level of knowledge of the respondents on the various rules governing the management and running of the boda boda business as set out in various Acts; if they believed that the method of appointing boda boda association officials was optimum; if they believed that there was a room for growth and advancement of oneself in the boda boda business; and if they felt that the income from boda boda business had been fairly utilized by their peers and association.

47.4per cent (27) of the respondents said that they were somehow aware of the rules and Acts governing the operations of their business. 78.9per cent (45) believed that the method of appointing boda boda association officials was not optimum at all. 91.2per cent (52) of the respondents believed that there was a room for growth and advancement of oneself in the boda boda business. 35.1per cent (20) of the respondents felt that the income from boda boda business was fairly utilized by their peers and association.

\subsection{Income Levels of the Boda Boda Cyclists at Household Levels}

This particular objective was to determine the extent to which boda boda business had led to the rise or otherwise of the income levels of the boda bodaoperators at household levels. To achieve this, the respondents were asked 6 questions including; if they felt that the boda boda business had made impact in alleviating poverty in their households; to state what things had improved in their households; if there was marked improvements in earnings as compared to their previous engagements; if they knew any project or anything else that had been funded out of the boda boda business in their area; how much, if at all, they felt that the boda boda business had contributed to the improvements in livelihoods in the households as whole; and state what projects they had undertaken as a result of the boda boda business. 56.1per cent (32) of the respondents believed that the boda boda business had helped them a lot in alleviating poverty in their households.

70.2per cent (40) of the respondents stated that education was the single most thing which had improved massively in their households. 66.7per cent (38) of the respondents believed that there was a marked improvement in their earnings as compared to their previous engagements. 42.1per cent (24) of the respondents said that they knew of projects in their area which had been funded using funds from the boda boda business. 54.4per cent (31) of the respondents said that the boda boda business had contributed a lot in improving their livelihoods in their households. 47.4per cent (27) of the respondents said that they had started a small kiosk as a result of the boda boda business of which 63.2per cent (36) said that the businesses were partly funded by boda boda business and funds from other sources such as bank loans and family grants.

\section{Conclusions}

The findings of this study are in agreement with existing literature. The findings can be seen to fit the existing literature as previous studies have used questionnaires as assessment instruments, descriptive research design and boda boda business as the independent variable. The government of Kenya removed the tax on motorcycles in 2008 to promote job creation in the transport sector; a significant number of young people enthusiastically joined the transport business. The motorcycle transport is commonly known as "boda boda" and the number of these motorbikes leaped from 3,759 units in 2005 to more than 91,151 in 2009 Kazi Kwa Vijana (KKV) manual.

This study therefore sought to explore the potential of commercial motorcycle operations in improving livelihoods, alleviating poverty and contributing to the general development of the economy. In particular, it focused on the earnings of the operators, improvement of household incomes, sources of funds, benefits to the communiy, utilization of funds accruing and spill-over effects (i.e projects initiated as a result of boda boda businesses). The overall aim is to stimulate policy debate around how 
best to streamline the boda boda business for purposes of tapping on its potential to improve living standards of the poor unemployed youths who dominate it in the context of general economic empowerment.

The findings of this study were that the boda boda business has contributed massively in alleviating poverty at the household level through increased incomes, job creation, community development projects as well as investment opportunities and options. Boda boda has also been widely accepted as a more efficient and reliable means of transport in the rural and peri-urban centres in Kenya. The boda boda operators have very little knowledge on the laws and rules governing their operations as well as the process of electing their representatives in the boda boda associations.

The boda boda business has led to massive improvement, development and enhancement of the Kenyan economy as a whole as goods and commodities are transported in time from the farm to the market place as well as the human capital. Several investment projects have also been set up in the rural and peri- urban areas as a result of the boda boda business.

\section{Recommendations}

The national government of Kenya, the county governments as well as policy makers should look into the findings of this study with keen interest as they have far reaching ramifications and have a potential to grow the Kenyan economy massively. They should ensure that there are clearly rules and policies governing the ownership and operations of the boda boda business in Kenya to ensure safety of both the operators and their passengers thereby reducing the accident incidents currently being witnessed. There is a need to organize and carry out civic education crusades and campaigns to sensitize the general public as well as the boda boda cyclists on the existing rules and traffic Acts governing their operations.

There is a need to sensitize the boda boda operators on the existing frameworks and policies which they can utilize to elect their association leaders democratically free of corruption, threats and intimidation. Setting up a micro-finance institution targeting the boda boda operators to educate them on how to start and run a successful enterprise as well as loaning them funds to initiate and operate those enterprises.

There is a need to educate and sensitize the boda boda operators on optimal ways of saving and managing their finances to improve their livelihoods even further. There is a need to encourage all boda boda operators to enroll in a legally registered association which they can use to increase their bargaining power for borrowing loans from finance lending institutions in order to start and run medium enterprises.

There is need for more funds collected from the boda boda business operations to be channeled in improving the general livelihoods of the local communities by coming up with projects such as schools, healthcareas well as infrastructure.

\section{References}

i. ILO. (2014). Global Employment Trends 2014: Risk of a jobless recovery? Retrieved from http:/ / www.ilo.org/ wcmsp5/ groups/ public/ ---dgreports/ ---dcomm/ --publ/ documents/ publication/ wcms_233953.pdf

ii. Karema, F. M. (2015). The role of commercial motorcycles in the rural economy:A case study of Laikipia east sub-county, Kenya, (October). https:/ / doi.org/ 10.1504/ WRITR.2017.082733

iii. Njenga, P., Kemtsop, G., Willilo, S., Opiyo, R., \& Hine, J. (2013). Rural Transport Service Indicators : Final Report.

iv. Omolo, J. (2012). The Role of the State in Economic Development: Employment Challenges in Kenya, 1-14.

v. Singoro, B. W., Wakhungu, J., Obiri, J., \& Were, E. (2016). Causes and Trends of Public Transport Motorcycle Accidents in Bungoma County, Kenya. International Journal of Multidisciplinary Academic Research, 4(1), 36-42. Retrieved from www.multidisciplinaryjournals.com

vi. Starkey, P. (2012). Towards safe, clean and affordable rural transport: present realities and recent trends edit Master. Management Sciences.

vii. Starkey, P. (2016). The benefits and challenges of increasing motorcycle use for rural access. International Conference on Transportation and Road Research, Mombasa, 15-17 March 2016,1-17.

viii. Yakubu, A. T. (2012). Determinants of Earnings among Commercial Motorcycle Operators in Kwara State , Nigeria. International Journal of Economics and Management Sciences Vol. 2, No. 2, 2012, Pp. 11-1, 2(2), 11-17. 